\title{
PROFIL ASAM LEMAK DAGING DOMBA LOKAL JANTAN YANG DIPELIHARA DI PEDESAAN PADA BOBOT POTONG DAN LOKASI OTOT YANG BERBEDA
}

\author{
E. Purbowati ${ }^{1}$ E. Baliarti', S.P.S. Budhi', dan W. Lestariana ${ }^{3}$
}

\begin{abstract}
INTISARI
Daging ternak ruminansia contohnya domba mengandung asam lemak jenuh lebih tinggi daripada nonruminansia. Konsumsi daging dengan asam lemak jenuh tinggi disarankan untuk dibatasi karena risiko terjadinya aterosklerosis yang dapat mengakibatkan jantung koroner. Tujuan penelitian ini adalah untuk mengetahui profil asam lemak daging domba lokal jantan pada bobot potong dan lokasi otot yang berbeda. Domba lokal yang digunakan sebagai subyek penelitian diperoleh dari daerah Temanggung, yaitu domba jantan sehat umur 1,5-12 bulan sebanyak 18 ekor, yang dipotong pada 6 kategori bobot potong (BP) dengan kisaran $5-30 \mathrm{~kg}$. Sampel daging yang dianalisis diambil dari otot pada bagian loin, paha, dan pundak. Data yang diperoleh dianalisis dengan analisis variansi pola tersarang dan dilanjutkan dengan uji Duncan apabila ada perbedaan antar kelompok. Hasil penelitian menunjukkan bahwa, pada bobot potong yang berbeda, menghasilkan daging dengan kadar asam lemak laurat, miristat, palmitat, dan palmittolleat yang berbeda nyata $(\mathrm{P}<0,05)$, sedangkan miristolat, heptakecanoat, stearat, oleat, linoleat, dan linolenat perbedaannya tidak nyata $(P>0,05)$. Kadar asam lemak laurat daging, dari yang paling rendah, dihasilkan dari BP $25,20,30,10$, 15 , dan 7 $\mathrm{kg}$ masing-masing 3,$86 ; 11,41 ; 12,29 ; 21,86 ; 27,03 ;$ dan $40,15 \mathrm{mg} / 100 \mathrm{~g}$ daging. Kadar asam lemak miristat daging dari yang paling rendah, dihasilkan dari $\mathrm{BP} 25,20,30,10,7$ dan $15 \mathrm{~kg}$ masing-masing 34,$57 ; 47,50 ; 58,34 ; 82,42 ; 111,17 ;$ dan $132,48 \mathrm{mg} / 100 \mathrm{~g}$ daging. Kadar asam lemak palmitat daging dari yang paling rendah dihasilkan dari $\mathrm{BP} 25,20,7,30,10$, dan $15 \mathrm{~kg}$ masing-masing 367,$10 ; 442,86$; 497,$78 ; 619,55 ; 638,44$; dan $851,94 \mathrm{mg} / 100 \mathrm{~g}$ daging. Kadar asam lemak palmitoleat daging, dari yang paling rendah, dihasilkan dari BP $10,7,30,25,20$, dan $15 \mathrm{~kg}$ masing-masing 45,$59 ; 52,09$; 137,$09 ; 220,95 ; 249,63$; dan $255,38 \mathrm{mg} / 100 \mathrm{~g}$ daging. Rerata kadar asam lemak miristat, heptakecanoat, stearat, oleat, linoleat, dan linolenat masing-masing 77,$75 ; 53,75 ; 342,81 ; 693,23$; 1448,42 ; dan $199,42 \mathrm{mg} / 100 \mathrm{~g}$ daging. Kadar lemak daging domba dari bagian loin, paha, dan pundak menunjukkan perbedaan yang tidak nyata $(P>0,05)$, namun secara kuantitatif daging dari bagian loin mengandung asam lemak yang lebih rendah. Kesimpulan penelitian ini adalah daging domba dengan kadar asam lemak laurat, miristat, dan palmitat yang paling rendah dapat diperoleh dari BP $25 \mathrm{~kg}$ (umur 9 bulan), sedangkan daging domba dengan kadar asam lemok palmitoleat yang paling tinggi diperoleh dari BP $15 \mathrm{~kg}$ (umur 5 bulan). Secara kuantitatif daging dari bagian loin mengandung asam lemakyang lebih rendah daripada dari bagian paha dan pundak.
\end{abstract}

(Kata kunci : Domba, Bobot potong, Jenis otot, Asam lemak).

Buletin Peternakan $29(2): 62-70,2005$

\footnotetext{
${ }^{4}$ Fakultas Peternakan Universitas Diponegoro Semarang.

${ }^{2}$ Fakultas Peternakan Universitas Gadjah Mada Yogyakarta.

${ }^{3}$ Fakultas Kedokteran Universitas Gadjah Mada Yogyakarta.
} 


\title{
FATTY ACIDS PROFILE OF LOCAL MALE LAMB REARED IN THE VILLAGE ON DIFFERENT SLAUGHTER WEIGHT AND MUSCLE
}

\begin{abstract}
Meat from lamb contained more saturated fatty acids than poultry. Consumption meat with high saturated fatty acids should be controlled due to aterosklerosis risk which lead to coroner heart attack. The objective of the research was to study fatty acids profile of local male lamb on different slaughter weight (SW) and muscle. Local lambs derived from Temanggung, aged 1.5-12 months were slaughtered at 6 categories SW with range $5-30 \mathrm{~kg}$. The lamb was slaughtered and sampled for fatty acids determination especially on loin, leg, and shoulder muscles. The nested ANOVA was used to analyze data and any differences among the groups were further tested using Duncan Multiple Range Tests (DMRT). The results showed that different SW produced different lauric, myristic, palmitic, and palmittoleic acids $(\mathrm{P}<0.05)$, but myristolic, heptadecanoic, stearic, oleic, linoleic, and linolenic acids were not significant $(\mathrm{P}>0.05)$. Low lauric acids content can be found from $25,20,30,10,15$ and $7 \mathrm{~kg}$ SW e.g. $3.86,11.41,12.29,21.86,27.03$ and $40.15 \mathrm{mg} / 100 \mathrm{~g}$ meat, respectively. Low myristat acids content were found from $25,20,30,10,7$ and $15 \mathrm{~kg} \mathrm{SW}$ e.g. $34.57,47.50,58.34,82.42,111.17$ and $132.48 \mathrm{mg} / 100 \mathrm{~g}$ meat, respectively. Low palmitic acids content were found from $25,20,7,30,10$ and $15 \mathrm{~kg} \mathrm{SW}$ e.g. 367.10, 442.86, 497.78, 619.55, 638.44 and $851.94 \mathrm{mg} / 100 \mathrm{~g}$ meat, respectively. Low palmitoleic acids content were from $10,7,30,25,20$ and $15 \mathrm{~kg} \mathrm{SW} \mathrm{e.g.} \mathrm{45.59,} \mathrm{52.09,} \mathrm{137.09,} \mathrm{220.95,}$ $249.63,255.38 \mathrm{mg} / 100 \mathrm{~g}$ meat, respectively. Average content of myristic, heptadecanoic, stearic, oleic, linoleic, and linolenic acids were 77.75, 53.75, 342.81, 693.23, 1448.42 and $199.42 \mathrm{mg} / 100 \mathrm{~g}$ meat, respectively. Fatty acids of lamb meat from loin, leg and shoulder were not significantly different $(\mathrm{P}>0.05)$, but from quantitative value of fatty acids from loin were lower. The lamb meat with the lowest lauric, myristic and palmitic acids were produced from $25 \mathrm{~kg} \mathrm{SW}$ (aged 9 months), but lamb meat with the highest palmitoleic acids from $15 \mathrm{~kg} \mathrm{SW}$ (aged 5 months). The quantitative value showed that fatty acids of lamb meat from loin were lower than lamb meat from leg and shoulder.
\end{abstract}

(Key words : Lamb, Slaughter weight, Muscle kinds, Fatty acids).

\section{Pendahuluan}

Dewasa ini, terutama di negara-negara maju dan masyarakat menengah ke atas, pangan yang dikonsumsi tidak hanya ditujukan untuk memenuhi kebutuhan akan zat-zat gizi bagi tubuh, namun telah memperhitungkan juga efeknya terhadap kesehatan. Salah satu efek yang diperhitungkan adalah risiko terjadinya aterosklerosis akibat sering mengkonsumsi pangan yang kadar lemaknya tinggi. Diketahui bahwa aterosklerosis adalah penyebab penyakit jantung koroner yang merupakan penyebab kematian manusia Indonesia di urutan pertama untuk usia di atas 40 tahun (Survai Kesehatan Rumah Tangga Nasional tahun 1992 dalam Lestariana, 2003).
Kadar lemak daging bervariasi, tergantung dari jumlah lemak eksternal dan lemak intramuskular. Ditinjau dari segi nutrisi, komponen lemak yang penting adalah trigliserida, fosfolipida kolesterol, dan vitamin yang terlarut dalam lemak. Trigliserida mengandung asam-asam lemak jenuh dan tidak jenuh. Asam lemak jenuh pada daging meliputi stearat dan palmitat, sedangkan asam-asam lemak tidak jenuh pada daging antara lain oleat, linoleat, dan linolenat (Soepamo, 1989).

Daging dari ternak ruminansia seperti sapi, kerbau, kambing, dan domba mengandung asam lemak jenuh yang lebih tinggi dibandingkan non ruminansia (Soeparno, 1995). Kandungan asam lemak jenuh daging domba lebih tinggi daripada daging sapi (Bahar, 2003). 
Komposisi asam lemak domba terdiri dari miristat, palmitat, palmitoleat, stearat, oleat, linoleat, dan lain-lain, masing-masing sebanyak $3,21,4,20,41,5$, dan $6 \mathrm{~g} / 100 \mathrm{~g}$ asam lemak total (Almatsier, 2001).

Konsumsi lemak, terutama asam lemak jenuh (saturated fatty acids), asam lemak tidak jenuh trans (trans unsaturated fatty acids), dan kolesterol merupakan faktor penting yang dapat meningkatkan low density lipoprotein (LDL) dalam darah dan mempertinggi risiko terjadinya penyempitan pembuluh darah koroner yang mengakibatkan manusia menderita penyakit jantung koroner (Supari, 2002). Hal ini disebabkan karena hampir seluruh trigliserida $(90 \%)$ terutama yang bersifat jenuh bisa diserap tubuh dengan mudah, sementara kolesterol makanan yang dapat diserap tubuh hanya 20$50 \%$ (Apriadji, 2003). Di dalam tubuh, asupan lemak makanan dibawa ke hati untuk diubah menjadi kolesterol, Agar mudah didistribukan ke seluruh tubuh, kolesterol berikatan dengan protein membentuk lipoprotein. Jika masih banyak mengandung kolesterol, maka ikatan lipoproteinnya sedikit mengandung protein sehingga berat jenisnya rendah (LDL). Dalam perjalanan LDL meninggalkan hati menuju ke seluruh jaringan tubuh, muatan kolesterol yang berlebihan akan mudah tercecer di sepanjang pembuluh darah. Akibatnya, dapat terjadi penyempitan arteri (aterosklerosis), yang bisa mengakibatkan stroke dan serangan jantung. Pola asupan lemak ideal adalah kurang $30 \%$ dari seluruh kalori yang terdiri dari $60 \%$ monousaturated fatty acids, $10 \%$ saturated fatty acids, dan sisanya polyunsaturated fatty acids dengan imbangan lemak omega 6 dan omega 3 adalah 4 dibanding 1.

Sebagai insan peternakan, hal-hal seperti tersebut di atas harus diperhatikan dalam usaha produksi daging ternak. Sifat kimia daging (termasuk komposisi asam lemak) bervariasi tergantung spesies hewan, umur, jenis kelamin, pakan, serta lokasi anatomis dan fungsi bagianbagian otot dalam tubuh (Romans et al., 1994; Rusman et al., 2000). Selain itu, bobot tubuh ternak ruminansia juga mempunyai hubungan yang erat dengan bobot komponen-komponen kimianya (Soeparno, 1994). Penelitian ini dar bertujuan untuk mengetahui profil asam lemak daging domba pada bobot potong dan lokasi otot yang berbeda. Lokasi otot yang diamati kadar asam lemak dagingnya adalah pada bagian loin (punggung), paha, dan pundak.

\section{Materi dan Metode}

Pemotongan ternak dan pengambilan sampel pada penelitian ini dilakukan di Laboratorium Ilmu Ternak Potong dan Kerja, Fakultas Peternakan Universitas Diponegoro Semarang selama 6 minggu. Analisis komposisi asam lemak daging dilakukan di Laboratorium Biokimia Pusat Antar Universitas, Universitas Gadjah Mada, Yogyakarta.

Domba lokal jantan sehat sebanyak 18 ekor dengan umur 1,5-12 bulan yang digunakan sebagai subyek penelitian diperoleh dari Kelompok Tani Ternak "Ngudi Raharjo" di desa Pagergunung, kecamatan Pringsurat, kabupaten Temanggung, untuk mendapatkan bangsa ternak dan latar belakang nutrisi yang sama. Domba tersebut dipotong dengan teknik pemotongan beruntun (Butterfield, 1988) pada 6 kategori bobot potong (BP) dengan kisaran 5-30 kg, yakni $5,10,15,20,25$ dan $30 \mathrm{~kg}$ sehingga ada 3 ekor domba sebagai ulangan pada setiap bobot potong.

Peralatan yang digunakan dalam penelitian ini adalah seperangkat alat untuk memotong ternak serta timbangan untuk menimbang ternak dan sampel daging. Timbangan untuk menimbang ternak adalah timbangan gantung (hanging scales) merk five goats buatan China dengan kapasitas $50 \mathrm{~kg}$ dan ketelitian $200 \mathrm{~g}$, sedangkan timbangan untuk menimbang sampel adalah timbangan elektronik merk adventurer OHAUS tipe AR1530 dengan kapasitas $150 \mathrm{~g}$ dan ketelitian $0,001 \mathrm{~g}$. Alat untuk menganalisis kadar asam lemak daging adalah gas chromatography.

Pemotongan domba sesuai dengan bobot potong yang telah ditentukan dilakukan secara halal setelah dipuasakan terhadap pakan selama 22 jam. Tujuan pemuasaan domba sebelum pemotongan adalah untuk memperkecil variasi bobot potong akibat isi saluran pencernaan dan untuk mempermudah pelaksanaan pemotongan. 
Air minum diberikan secara ad libitum.

Pemotongan ternak dimulai dengan memotong leher hingga vena jugularis, oesophagus, dan trachea terputus (dekat tulang rahang bawah) agar terjadi pengeluaran darah yang sempurna. Kemudian ujung oesophagus diikat agar cairan rumen tidak keluar apabila ternak tersebut digantung. Kepala dilepaskan dari tubuh pada sendi occipito-atlantis. Kaki depan dan kaki belakang dilepaskan pada sendi carpo-metacarpal dan sendi tarso-metatarsal. Ternak tersebut digantung pada tendo-achiles pada kedua kaki belakang, kemudian kulitnya dilepas.

Karkas segar diperoleh setelah semua organ tubuh bagian dalam dikeluarkan, yaitu alat reproduksi, hati, limpa, jantung, paru-paru, trachea, alat pencernaan, empedu, dan pancreas, kecuali ginjal. Karkas segar ini dipotong ekornya, kemudian dibelah secara simetris sepanjang tulang belakangnya dari leher (Ossa vertebrae cervicalis) sampai sakral (Ossa vertebrae sarcalis) sehingga diperoleh karkas segarkiri dan kanan.

Sampel daging untuk analisis asam lemak diambil dari karkas sebelah kanan pada bagian loin, paha, dan pundak. Preparasi metilasi asam lemak daging dilakukan dengan metode transesterifikasi in situ (Park dan Goins, 1994) dan pembacaan kadar asam lemak daging dengan alat gas chromatography.

Data hasil penelitian dianalisis dengan analisis variansi pola tersarang/hierarchi (Astuti, 1980). Untuk mengatasi keheterogenan ragam dan ketidaknormalan data, sebelum dianalisis data ditransformasi ke logaritma karena tranformasi ini cocok untuk data bilangan bulat yang mencakup wilayah nilai yang lebar (Gomez dan Gomez, 1995). Apabila terjadi perbedaan dari uji yang dilakukan, maka dilanjutkan dengan uji wilayah ganda Duncan (Stell dan Torrie, 1991).

\section{Hasil dan Pembahasan}

Asam lemak daging domba yang dapat diidentifikasi pada penelitian ini ada 10 macam yang terdiri dari asam-asam lemak jenuh (laurat, miristat, palmitat, heptadekanoat, dan stearat) dan asam-asam lemak tidak jenuh (miristolat, palmitoleat, oleat, linoleat dan linolenat).Urutan kadar asam lemak daging domba tersebut (per $100 \mathrm{~g}$ daging) dari yang terbanyak adalah linoleat $(\mathrm{Cl} 8: 2)=1448,42 \mathrm{mg}(40,33 \%)$, oleat $(\mathrm{C} 18: 1)=693,23 \mathrm{mg}(19,30 \%)$, palmitat $(\mathrm{C} 16: 0)$ $=569,61 \mathrm{mg}(15,86 \%)$, stearat $(\mathrm{C} 18: 0)=342,81$ mg $(9,54 \%)$, linolenat $(\mathrm{C} 18: 3)=199,42 \mathrm{mg}$ $(5,55 \%)$, palmitoleat $(\mathrm{C} 16: 1)=160,12 \mathrm{mg}$ $(4,46 \%)$, miristat $(\mathrm{C} 14: 0)=77,75 \mathrm{mg}(2,16 \%)$, heptadekanoat $(\mathrm{Cl} 7: 0)=53,75 \mathrm{mg}(1,50 \%)$, miristolat $(\mathrm{C} 14: 1)=27,07 \mathrm{mg}(0,75 \%)$, dan laurat $(\mathrm{Cl2}: 0)=19,44 \mathrm{mg}(0,54 \%)$. Untuk lebih jelasnya, profil asam lemak daging domba hasil penelitian ini dapat dilihat pada Gambar 1 .

Dari Gambar 1 dapat dilihat bahwa asam lemak daging domba yang digunakan sebagai subyek penelitian sebagian besar $(85,03 \%)$ terdiri dari linoleat, oleat, palmitat, dan stearat. Pada sapi Angus, Hereford, Fries Holand dan Murray Grey, asam lemak daging yang utama adalah oleat, palmitat, linoleat, dan stearat (Rusman et al., 2000).

Asam lemak linoleat adalah asam lemak tidak jenuh berikatan rangkap dua yang disebut Poly Unsaturated Fatty Acid (PUFA). Berdasarkan letak atau posisi ikatan rangkap terhitung dari gugus metil pada rantai karbon molekul asam lemak, linoleat dikenal sebagai asam lemak omega-6. Asam lemak linoleat merupakan salah satu asam lemak esensial bagi tubuh manusia, artinya harus tersedia dalam makanan sehari-hari karena tidak dapat disintesis di dalam tubuh. Asam-asam lemak esensial sangat baik bagi perkembangan otak, susunan syaraf pusat maupun syaraf tulang punggung. Kekurangan asam lemak esensial dapat menghambat pertumbuhan bayi dan anakanak, kegagalan reproduksi, gangguan pada kulit, ginjal dan hati serta mengakibatkan degenerasi (kerusakan) bagian-bagian susunan syaraf yang diperkirakan dapat menyebabkan kehilangan daya ingat pada usia menengah dan menurunnya fungsi otak secara drastis (Almatsier, 2001; Khomsan, 2004).

Khasiat asam linoleat baik bagi kesehatan tubuh karena asam lemak ini bermanfaat untuk mencegah terjadinya gangguan pertumbuhan, gangguan fertilitas, kerapuhan sel darah merah, 


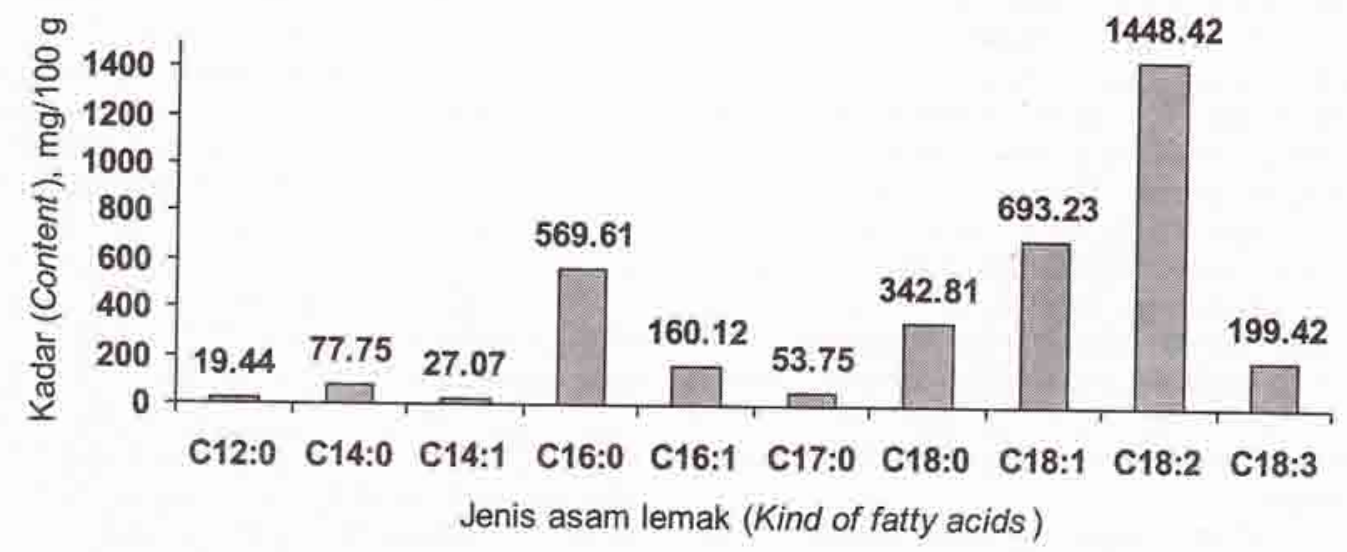

Gambar 1. Profil asam lemak daging domba lokal (Fatty acids profile of local lamb).

dan gangguan pada sistem kekebalan tubuh (Khomsan, 2004). Dewasa ini banyak ahli nutrisi tertarik dengan khasiat asam lemak linoleat dalam bentuk terkonjugasi yang disebut CLA (conjugated linoleic acid) karena terbukti penting bagi kesehatan, yakni dapat menghambat pertumbuhan kanker, mengurangi risiko penyakit jantung dan diabetes, menstimulasi fungsi kekebalan, serta merupakan faktor pertumbuhan. Secara alami, CLA banyak terdapat di dalam susu, daging, dan produkproduk olahannya. Laporan Yulianto yang disitasi oleh Legowo (2004) menunjukkan bahwa kadar CLA yang tinggi terdapat pada daging domba $(1,20 \%)$, daging sapi $(0,60 \%)$, susu $(0,98 \%)$, dan mentega $(0,97 \%)$, dengan persentase berdasarkan kadar total lemaknya.

Asam lemak oleat juga merupakan asam lemak tidak jenuh tetapi berikatan rangkap tunggal yang disebut MUFA (mono unsaturated fatty acid). Asam lemak oleat dikenal juga sebagai asam lemak omega-9. Asam lemak ini memiliki daya perlindungan tubuh yang mampu menurunkan kadar kolesterol LDL dan meningkatkan kadar kolesterol High Density Lipoprotein (HDL) (Apriadji, 2003; Khomsan, 2004). Kolesterol HDL sering disebut sebagai kolesterol baik karena mengandung protein dalam jumlah besar dan kolesterol dalam jumlah kecil, sehingga mampu mengambil sisa-sisa kolesterol di dalam pembuluh darah dan membawanya kembali ke hati untuk dikeluarkan dari tubuh (Legowo, 1996).

Asam lemak palmitat dan stearat adalah asam lemak jenuh (saturated fatty acid). Palmitat merupakan bahan dasar untuk pembentukan asam lemak lainnya, karena merupakan asam lemak terpanjang atom C-nya yang dianalisis secara denovo (Lehninger, 1990; Meyes, 1999). Asam lemak palmitat selanjutnya dapat mengalami perpanjangan rantai dalam retikulum endoplasmik menjadi asam lemak rantai panjang lainnya. Kadar asam palmitat yang tinggi di dalam daging tidak diinginkan konsumen karena bersifat hiperlipidemik dan dapat meningkatkan kolesterol darah, sedangkan peningkatkan proporsi asam stearat dalam daging menguntungkan karena asam lemak ini bersifat hipokolesteremik pada manusia (Mandell et al., 1997). Kolesterol darah orang dewasa yang aman (normal) adalah kurang dari $200 \mathrm{mg} / \mathrm{dl}$ (Hui dalam Legowo, 1999).

Profil asam lemak daging domba lokal pada BPyang berbeda

Domba dengan kategori BP $5 \mathrm{~kg}$ sulit diperoleh di lokasi penelitian, sehingga BP paling kecil $6,80 \mathrm{~kg}$. Umur domba pada setiap kategori BP adalah sekitar 1,$5 ; 3 ; 5 ; 7 ; 9 ;$ dan 12 bulan masing-masing untuk rerata BP 7,07 ; 
10,$13 ; 15,13 ; 20,27 ; 25,20 ;$ dan $30,13 \mathrm{~kg}$. Profil asam lemak daging domba lokal pada bobotpotong yang berbeda pada Tabel 1. Dari Tabel 1 dapat dilihat bahwa pada bobot potong yang berbeda menghasilkan daging dengan kadar asam lemak laurat, miristat, palmitat, dan palmitoleat yang berbeda nyata $(P<0,05)$, sedangkan perbedaan kadar asam lemak daging untuk miristolat, heptadekanoat, stearat, oleat, linoleat, dan linolenat tidak nyata $(\mathrm{P}>0,05)$.

Kadar asam lemak laurat daging domba dari yang paling rendah, dihasilkan pada BP 25 , $20,30,10,15$, dan $7 \mathrm{~kg}$. Kadar asam lemak miristat daging domba, dari yang paling rendah, dihasilkan pada BP $25,20,30,10,7$, dan $15 \mathrm{~kg}$. Kadar asam lemak palmitat daging domba dari yang paling rendah dihasilkan pada BP $25,20,7$, 30,10 , dan $15 \mathrm{~kg}$. Kadar asam lemak palmitoleat daging domba, dari yang paling rendah, dihasilkan pada BP $10,7,30,25,20$, dan $15 \mathrm{~kg}$.

Kadar asam lemak laurat, miristat, dan palmitat (asam-asam lemak jenuh) daging domba yang paling rendah adalah dari BP $25 \mathrm{~kg}$ (umur 9 bulan) kemudian diikuti oleh BP $20 \mathrm{~kg}$ (umur 7 bulan), sedangkan untuk kadar asam lemak palmitoleat (asam lemak tidak jenuh) daging domba yang paling rendah dari BP $10 \mathrm{~kg}$ (umur 3 bulan) dan yang tertinggi dari BP $15 \mathrm{~kg}$ (umur 5 bulan).

Perbedaan yang nyata dari kadar asamasam lemak di atas tidak menunjukkan pola yang pasti. Laporan Armin yang disitasi Soebagyo et al. (2000) menyatakan bahwa ternak ruminansia yang mengkonsumsi pakan yang mengandung asam lemak tidak jenuh mempunyai pengaruh yang kecil terhadap penyimpanan asam lemak tidak jenuh di dalam tubuh ternak tersebut karena adanya mikroflora rumen yang dapat menghidrolisis dan menghidrogenasi asamasam lemak tidak jenuh. Waktu penggemukan yang cukup lama dapat memberikan kesempatan kepada mikroflora rumen untuk menghidrolisis asam lemak tidak jenuh dalam pakan menjadi asam lemak jenuh dalam daging. Hal ini telah dibuktikan oleh Soebagyo et al. (2000), bahwa semakin lama waktu penggemukan sapi akan menghasilkan daging dengan kadar asam lemak jenuh yang lebih tinggi dan asam lemak tidak jenuh yang lebih rendah $(P<0,05)$. Berdasarkan kenyataan ini, maka Cook dalam Lawrie (1995) menyarankan agar pemberian pakan dengan asam lemak tidak jenuh bagi ruminansia dalam usaha untuk meningkatkan ketidakjenuhan asam lemak dagingnya, maka perlu diberi formaldehit

Tabel 1. Profil asam lemak daging domba lokal pada bobot potong yang berbeda (Fatty acids profile of local lamb on different slaughter weight)

\begin{tabular}{|c|c|c|c|c|c|c|}
\hline \multirow{2}{*}{$\begin{array}{c}\text { Asam lemak (Fatty acids) } \\
(\mathrm{mg} / 100 \mathrm{~g})\end{array}$} & \multicolumn{6}{|c|}{ Rataan bobot potong (Average of slaughter weight) } \\
\hline & $7,07 \mathrm{~kg}$ & $10,13 \mathrm{~kg}$ & $15,13 \mathrm{~kg}$ & $20,27 \mathrm{~kg}$ & $25,20 \mathrm{~kg}$ & $30,13 \mathrm{~kg}$ \\
\hline Lauric acid (C12:0) & $40,15^{t}$ & $21,86^{\mathrm{d}}$ & $27,03^{c}$ & $11,41^{b}$ & $3,86^{\mathrm{a}}$ & $12,29^{c}$ \\
\hline Myristic acid (C14:0) & $111,17^{e}$ & $82,42^{\text {d }}$ & $132,48^{f}$ & $47,50^{6}$ & $34,57^{\mathrm{a}}$ & $58,34^{\mathrm{c}}$ \\
\hline Myristolic acid (C14:1) & 37,93 & 26,17 & 32,17 & 27,36 & 17,53 & 20,75 \\
\hline Palmitic acid (C16:0) & $497,78^{\mathrm{e}}$ & $638,44^{e}$ & $851,94^{f}$ & $442,86^{b}$ & $367,10^{\mathrm{B}}$ & $619,55^{\mathrm{d}}$ \\
\hline Palmitoleic acid (C16:1) & $52,09^{\mathrm{b}}$ & $45,59^{\mathrm{a}}$ & $255,38^{f}$ & $249,63^{\mathrm{e}}$ & $220,95^{\text {d }}$ & $137,09^{\mathrm{c}}$ \\
\hline Heptadecanoic acid (C17:0) & 51,84 & 46,05 & 64,60 & 62,09 & 50,20 & 47,70 \\
\hline Stearic acid (C18:0) & 367,39 & 323,73 & 442,55 & 326,48 & 286,29 & 310,41 \\
\hline Oleic acid (C18:1) & 684,24 & 684,34 & 887,31 & 682,89 & 570,07 & 650,56 \\
\hline Linoleic acid (C18:2) & 1247,17 & 1206,95 & 2042,48 & 1576,77 & 1337,53 & 1279,60 \\
\hline Linolenic acid (C18:3) & 287,93 & 157,49 & 218,41 & 179,33 & 168,76 & 184,62 \\
\hline
\end{tabular}

$\bar{a}, b, c, c, e, 1$ Huruf yang berbeda pada baris yang sama menunjukkan perbedaan yang nyata $(\mathrm{P}<0,05)$

(Different superscript at the same raw indicating significant differences $(P<0.05)$ ). 
terlebih dahulu agar asam lemak pakan tersebut tidak dihidrolisis oleh mikroflora rumen.

Rerata kadar asam lemak miristolat, heptadekanoat, stearat, oleat, linoleat, dan linolenat masing-masing adalah 27,$07 ; 53,75$; 342,$81 ; 693,23 ; 1448,42$; dan $199,42 \mathrm{mg} / 100 \mathrm{~g}$ daging. Seperti telah disebutkan di atas, asam lemak heptadekanoat dan stearat termasuk asamasam lemak jenuh, sedangkan miristolat, oleat, linoleat, dan linolenat adalah asam-asam lemak tidak jenuh. Seperti halnya asam linoleat, asam linolenat juga esensial bagi tubuh manusia. Asam linolenat termasuk PUFA dan dikenal dengan nama asam lemak omega-3. Manfaat omega-3 bagi kesehatan tubuh yakni sebagai bahan penyusun lemak struktural yang membangun $60 \%$ bagian otak manusia (Khomsan, 2004). Asam lemak ini merupakan zat gizi penting bagi perkembangan bayi, terutama bagi perkembangan fungsi syaraf dan penglihatan. Peningkatan kekebalan tubuh, penghambatan beberapa jenis kanker juga sangat dipengaruhi oleh asam lemak omega-3. Risiko penyakit jantung koroner dapat diturunkan hingga $50 \%$ dengan mengkonsumsi zat ini, karena kemampuannya menekan LDL sehingga mengurangi risiko aterosklerosis, namun yang perlu diwaspadai adalah konsumsi asam lemak omega-3 (dan omega-6) secara berlebihan juga dapat menurunkan kolesterol HDL (Apriadji, 2003; Khomsan, 2004).

\section{Profil asam lemak daging domba lokal pada jenis otot yang berbeda}

Profil asam lemak daging domba lokal pada jenis otot yang berbeda dapat dilihat pada Tabel 2. Dari Tabel 2 dapat dilihat bahwa kadar lemak daging domba dari bagian loin, paha, dan pundak menunjukkan perbedaan yang tidak nyata $(P>0,05)$. Perbedaan yang tidak nyata dari kadar asam lemak daging pada ketiga lokasi otot ini kemungkinan karena domba dipelihara dengan cara dikandangkan terus menerus sehingga aktivitas gerak pada otot paha dan pundak terbatas yang berakibat lemak cenderung ditimbun pada bagian tersebut seperti halnya pada otot loin yang kurang digunakan untuk bergerak.

Secara kuantitatif dapat dilihat pada Tabel
2, bahwa kadar asam lemak daging domba pada bagian pundak cenderung paling tinggi, kemudiaan diikuti pada bagian paha dan paling rendah pada bagian loin. Hal ini dapat dipakai sebagai acuan bagi konsumen dalam memilih bagian daging untuk dikonsumsi. Bagi konsumen yang menginginkan daging dengan kadar asam lemak yang relatif lebih rendah dapat memilih daging dari bagian loin.

\section{Kesimpulan}

Dari hasil penelitian ini dapat disimpulkan bahwa sebagian besar asam lemak daging domba terdiri dari asam linoleat, oleat, palmitat, dan stearat. Daging domba dengan kadar asam lemak laurat, miristat, dan palmitat (asam-asam lemak jenuh) yang rendah dapat diperoleh dari BP $25 \mathrm{~kg}$ (umur 9 bulan), sedangkan daging domba dengan kadar asam lemak palmittoleat (asam lemak tidak jenuh) yang tinggi dapat diperoleh dari BP $15 \mathrm{~kg}$ (umur 5 bulan). Kadar asam lemak daging dari bagian loin, paha, dan pundak ada perbedaan yang tidak nyata, tetapi secara kuantitatif daging dari bagian loin cenderung mengandung asam lemak yang lebih rendah.

\section{Ucapan Terima Kasih}

Ucapan terima kasih disampaikan kepada (1) Rektor UGM dan Direktorat Jenderal Pendidikan Tinggi, Departemen Pendidikan Nasional, yang telah memberikan kesempatan dan Beasiswa Pendidikan Pascasarjana (BPPS) kepada penulis untuk mengikuti program S-3 di Sekolah Pasca Sarjana UGM; (2) Rektor dan Dekan Fakultas Peternakan UNDIP, yang telah memberikan ijin kepada penulis untuk mengikuti program S-3; (3) Prof. Dr. Ir. C. Imam Sutrisno yang telah memberikan sumbang saran dari perencanaan hingga pelaksanaan penelitian ini; (4) Ketua Lembaga Penelitian Universitas Diponegoro beserta staf dan Bagian Proyek Peningkatan Kualitas Sumberdaya Manusia, Direktorat Jenderal Pendidikan Tinggi, Departemen Pendidikan Nasional, yang telah memberikan kesempatan untuk memperoleh dana penelitian Hibah Bersaing yang sangat 
Tabel 2. Profil asam lemak daging domba lokal pada otot yang berbeda (Fatty acid profile of local lamb on different muscle)

\begin{tabular}{lccc}
\hline \multirow{2}{*}{$\begin{array}{c}\text { Asam lemak (Fatty acids) } \\
\text { (mg/100g) }\end{array}$} & \multicolumn{3}{c}{ Lokasi otot (Location of muscle) } \\
\cline { 2 - 4 } & Punggung (Loin) & Paha (Leg) & Bahu (Shoulder) \\
\hline Lauric acid (C12:0) & 17,57 & 15,80 & 24,94 \\
Myristic acid (C14:0) & 69,55 & 77,25 & 86,45 \\
Myristolic acid (C14:1) & 28,19 & 26,57 & 26,47 \\
Palmitic acid (C16:0) & 505,46 & 578,46 & 624,92 \\
Palmitoleic acid (C16:1) & 128,42 & 191,65 & 160,30 \\
Heptadecanoic acid (C17:0) & 46,19 & 58,42 & 56,63 \\
Stearic acid (C18:0) & 298,62 & 356,29 & 373,52 \\
Oleic acid (C18:1) & 613,03 & 732,82 & 733,86 \\
Linoleic acid (C18:2) & 1259,44 & 1513,61 & 1572,20 \\
Linolenic acid (C18:3) & 145,34 & 269,61 & 183,33 \\
\hline
\end{tabular}

membantu pelaksanaan penelitian ini; (5) Aries Rudi Setiawan dan kawan-kawan yang membantu pelaksanaan penelitian; serta (6) Rekan-rekan di Laboratorium Ilmu Ternak Potong Fakultas Peternakan UNDIP yang telah memberikan dukungan sepenuhnya pada penelitian ini.

\section{Daftar Pustaka}

Almatsier, S. 2001. Prinsip Dasar Ilmu Gizi. PT. Gramedia Pustaka Utama, Jakarta.

Apriadji, W. H. 2003. Sukses mengontrol kelebihan kolesterol. Nirmala. 05/V/Mei 2003: 18-21.

Astuti, M. 1980. Rancangan Percobaan dan Analisa Statistik Bagian I. Bagian Pemuliaan Ternak Fakultas Peternakan UGM, Yogyakarta.

Bahar, B. 2003. Panduan Praktis Memilih Produk Daging Sapi. PT. Gramedia Pustaka Utama, Jakarta.

Butterfield, R. M., 1988. New Concepts of Sheep Growth. The Departement of Veterinary Anatomy. University of Sydney, Sydney.

Gomez, K. A. dan A. A. Gomez. 1995. Prosedur Statistik untuk Penelitian Pertanian. Diterjemahkan oleh : E. Sjamsuddin dan J. S. Baharsjah. UI-Press, Jakarta.

Khomsan, A. 2004. Peranan Pangan dan Gizi untuk Kualitas Hidup. PT. Gramedia
Widiasarana Indonesia, Jakarta.

Lawrie, R.A. 1995. Ilmu Daging. Diterjemahkan oleh:A. Parakkasi. UI-Press, Jakarta.

Legowo, A. M. 1996. Masalah lemak dan kolesterol dalam bahan pangan hewani. Media. Edisi II Tahun XXI, Juni 1996: 815.

Legowo, A. M. 2004. Kajian tentang pengembangan produk ternak rendah lemak dan tinggi asam lemak tidak jenuh. Jurnal Pengembangan Peternakan Tropis. $29(4): 225-233$.

Lehninger, A. L. 1990. Dasar-dasar Biokimia Jilid 2. Cetakan Pertama. Diterjemahkan oleh: M. Thenawidjaja. Penerbit Erlangga, Jakarta.

Lestariana, W. 2003. Tinjauan Biokimiawi Pola Makan untuk Mencegah Penyakit Defisiensi dan Penyakit Degeneratif. Pidato Pengukuhan Jabatan Guru Besar. Fakultas Kedokteran, Universitas Gadjah Mada, Yogyakarta.

Mandell, I. B., J. G. Buchanan-Smith, B. J. Holub, dan C. P. Campbell. 1997. Effect of fish meal in beef cattle diets on growth performance, carcass characteristics, and fatty acid composition of longissimus muscle. J.Anim. Sci. 75: 910-919.

Meyes, P. A. 1999. Biosintesis Asam Lemak. Dalam: Biokimia Harper. R. K. Murray, D. K. Granner, P. A. Mayes, dan V. W. Rodwel, Eds. Diterjemahkan oleh : A. 
Hartono. Penerbit Buku Kedokteran EGC, Jakarta. PP. 222-229.

Park, P. W. dan R. E. Goins. 1994. In situ preparation of fatty acids methyl ester for analysis of fatty acids composition in foods. J. Food Sci. 59 (6): 1262-1266.

Romans, J. R., W. J. Costello, C.W. Carlson, M.L. Greaser dan K.W. Jones. 1994. The Meat We Eat. Interstate Publishers, Inc. Danville, Illinois.

Rusman, Soeparno, Setiyono, dan A. Suzuki. 2000. Characteristics of biceps femoris and longissimus thoracis muscle of five cattle breeds grown in a feedlot system. J. Anim. Sci. 74: 59-65.

Soebagyo, Y., N. Ngadiono, dan Z. Bachrudin. 2000. Pengaruh lama penggemukan terhadap pertambahan bobot badan harian dan komposisi asam lemak daging sapi brahman cross. Animal Production. Vol 2 (1):33-39.

Soeparno. 1989. Kimia dan Nutrisi Daging. Fakultas Peternakan. Universitas Gadjah Mada, Yogyakarta.

Soeparno. 1994. Ilmu dan Teknologi Daging. Gadjah Mada University Press, Yogyakarta.

Soeparno. 1995. Teknologi Produksi Karkas dan Daging. Fakultas Peternakan, Program Pascasarjana IImu Peternakan, Universitas Gadjah Mada, Yogyakarta.

Stell, R. G. D. dan J. H. Torrie. 1991. Prinsip dan Prosedur Statistika. Edisi Kedua. Diterjemahkan oleh: B. Sumantri. PT Gramedia Pustaka Utama, Jakarta. 